\title{
Feeding habit of goats in the scavenging system of Bangladesh
}

\author{
MR Alam \\ Dept of General Animal Science, Bangladesh Agricultural University, Mymensingh, Bangladesh
}

In the mixed farming system goats are reared mostly by the landless farmers to supplement their income. Feeding of goats depend on systems combining roadside, communal grazing and browsing of various vegetation. Investigation on utilization of these feed resources is required for devising of effective grazing management systems. The study involved the determination of nutritive values and feeding behaviour of the herbages available to goats.

Twenty goats of 6-24 months of age and 7-18 $\mathrm{kg}$ Live weight, belong to farmers were allowed to thrive on natural vegetation, predominantly grasses (Digitaria sanguinalis, Pancicum repens, Cynodon dactylon), plant leaves (Erythrina indica, Moringa oleifera, Zizyphus jujuba, Streblus asper) and shrubs (Mikania scandens wild, Dioscorea spp., Stephania hernandifalia walp) throughout the year. They remained in the field till late afternoon and feeding pattern of goats was monitored twice a week during Winter-Spring (WS), Summer (S), Monsoon (M) and Autumn (A). Samples of the herbages were collected during the observation for determination of composition and degradability of OM (DOM) upto $72 \mathrm{~h}$ was studied in the rumen of fistulated cows. Grazing and browsing behaviour were monitored and expressed as the percentage of time spent on biting grass sward (TSG), browse plants and shrubs (TSB).

The grasses and browse plants are not markedly different in composition and potential degradability between the seasons. There was a trend for $1-2 \%$ less CP content in the dry season (Winter-Spring). The herbages were more readily available in summer and monsoon followed by Autumn and WinterSpring. Seasonal availability of the herbages appear to influence the nature of the intake of the herbages rather than the composition. In the Summer there was abundance of regrowth of the herbages. In this situation $45 \%$ more grazing time was exhibited and preferences of goats for tender leaves and shoots were pronounced. In the Autumn and Winter-Spring seasons shifted to $14 \%$ more browsing and to a less extent to grazing. They were found to show distinct preference for young forages and spent $18 \%$ of grazing time in selecting forages. This preference for the forages appeared to be seasonal (Devendra 1978, World Rev Anim Prod, 14, 9-22) and availability may decrease feed intake (Nicol and Collins, 1986, Proc NZ Soc Anim Prod,46, 143-146). Low live-weight gain in goats during lean period may be explained by difference in herbage mass available (Alam, 1992, IAEA-TECDOC-691, 135-143).

This suggest that grazing preference of goats is depend on the availability of forages. They may have stronger preferences for tender vegetative parts of the forages and reluctant to change to less preferred herbages. This habit gradually shifted to browsing of young vegetation as the herbage mass decreased. In the co-grazing situation goats may perform better in terms of utilization of natural vegetation and productivity per unit area of land.

$\begin{array}{cc}\text { Parameters } & S \\ \text { CP } & 10.4 \\ \text { NDF } & 55.6 \\ \text { Lignin } & 18.9 \\ \text { DOM } & 67.3 \\ \text { TSG } & 70 \\ \text { TSB } & 25\end{array}$

\begin{tabular}{cc}
$M$ & $A$ \\
\hline 9.8 & 9.3 \\
57.6 & 58.4 \\
19.3 & 21.2 \\
68.8 & 65.4 \\
58 & 39 \\
30 & 46
\end{tabular}

WS

$8 . \overline{7}$

56.9

20.5

66.1

32

48 